\title{
Hepatic steatosis in six-banded armadillo (Euphractus sexcinctus Linnaeus, 1758)
}

\author{
Andrezza Braga Soares da Silva ${ }^{I^{*}}$ (D), Marcia dos Santos Rizzo ${ }^{1}$ (D), Alicia Viloria-Petit ${ }^{2}$ \& \\ Airton Mendes Conde Junior \\ ${ }^{1}$ Universidade Federal do Piaui, Iningua, CEP 64049-550, Teresina, PI, Brasil \\ ${ }^{2}$ University of Guelph, Guelph, Ontario, Canada \\ *Corresponding author: Andrezza Braga Soares da Silva,e-mail: andrezzab1@hotmail.com
}

SILVA, A. B. S. DA, RIZZO, M. DOS S., VILORIA-PETIT, A., CONDE JUNIOR, A. M. Hepatic steatosis in sixbanded armadillo (Euphractus sexcinctus Linnaeus, 1758). Biota Neotropica. 18(1): e20180442. http://dx.doi. org/10.1590/1676-0611-BN-2017-0442

\begin{abstract}
The six-banded armadillo (Euphractus sexcinctus) stands out among wild mammals due to the rare occurrence of spontaneous metabolic diseases. When altered, the liver, which is important in metabolism, may trigger a dysfunctional cascade, leading to hepatic steatosis. Here we describe a case of hepatic steatosis in a six-banded armadillo living in captivity. The female specimen was captured and donated to the Federal University of Piaui under SISBIO authorization $\mathrm{n}^{\circ}$ 53303. The animal was first referred for a veterinary clinical evaluation, and then euthanized following the ethical standards of the Federal Council of Veterinary Medicine. At the start of the dissection, the abdominal cavity was accessed and sections of all ex situ liver lobes, spleen and mandibular lymph node were subjected to routine histological processing; the results were photo documented. The anatomic and histopathological analysis confirmed the diagnosis of hepatic steatosis, which we propose is related to an infectious process as a result of the changes observed in the organs of the lymphoid system. This report of fatty liver disease in armadillo suggests an acute infectious process with lymphoid system involvement.
\end{abstract}

Keywords: Euphractus sexcinctus, infectious, liver, six-banded armadillo, steatosis.

\section{Esteatose hepática em tatu-peba (Euphractus sexcinctus Linnaeus, 1758)}

Resumo: O tatu-verdadeiro (Euphractus sexcinctus) se destaca entre os mamíferos selvagens devido à rara ocorrência de doenças metabólicas espontâneas. Quando alterado, o fígado, que é importante no metabolismo, pode desencadear uma cascata disfuncional, levando a esteatose hepática. Foi descrito um caso de esteatose hepática em um tatu-verdadeiro vivendo em cativeiro. O espécime feminino foi capturado e doado para a Universidade Federal do Piauí sob a autorização SISBIO n53303. O animal foi encaminhado para uma avaliação clínica veterinária e, depois, submetido à eutanásia seguindo os padrões éticos do Conselho Federal de Medicina Veterinária. No início da dissecção, acessou-se a cavidade abdominal e as seções de todos os lóbulos do fígado ex situ, do baço e do linfonodo mandibular foram submetidos ao processamento histológico de rotina. Os resultados foram fotomicrografados e documentados. A análise anatômica e histopatológica confirmou o diagnóstico de esteatose hepática, que está relacionada a um processo infeccioso como resultado das mudanças observadas nos órgãos do sistema linfóide. Este relatório de doença hepática gordurosa no armadillo sugere um processo infeccioso agudo com comprometimento do sistema linfático.

Palavras-chaves: Euphractus sexcinctus, infecção, fígado, tatu-verdadeiro, esteatose.

\section{Introduction}

Among wild mammals, the six-banded armadillo (Euphractus sexcinctus Linnaeus, 1758) stands out for its wide territoriality as well as having varied eating habits, including dietary fruit, leaves and insects (Abba \& Superina 2010). The cases of death involving armadillos in nature are related to poaching, unlike those in captivity, which are due to cage injuries, illnesses associated with food, and respiratory infections (Diniz et al., 1997). Spontaneous diseases are rarely reported in these animals, except for a single case of squamous cell carcinoma
(Bo-ram et al., 2015). Most agents already isolated in these animals do not cause symptoms; it is not yet known whether the immune system is effective or deficient, making them potential reservoirs of fungal, bacterial, parasitic and viral infections (Capellao et al., 2015).

The liver is an important organ that carries glandular endocrine and exocrine functions in the body, which allows it to perform many vital functions essential to maintaining homeostasis. Among its main activities, the following stand out: the regulation of nutrient metabolism, the immune role, the synthesis of proteins and other molecules, the storage of vitamins and iron, hormone degradation, and the excretion of drugs and toxins 
(Rouiller, 2013). It also confers, control the cell cycle and hepatic cells regeneration by compensatory mechanisms involved in hyperplasia of cells affected in tumor processes (Jesus et al., 2000, Beier, 2016).

When external factors culminate in disruption of liver function, serial reactions are initiated which modify the dynamics of the body. The accumulation of triglycerides inside the liver, for example, leads to the situation referred to as "fatty liver", in which the organ is yellowish and engorged with fat, characteristic of hepatic steatosis (Brunt \& Tiniakos 2010). This is due to changes in the metabolism of fatty acids, possibly related to an increase in its synthesis, and/or insufficient catabolism or transport and excretion from the liver (Silva \& Goncalves 2008).

Hepatic steatosis is frequently found in domestic animals, especially cats, most often animals deprived of food or undergoing periods of appetite loss (Silva, 2012). Potential causes of abnormal hepatic function include viral hepatitis, autoimmune liver diseases, hepatobiliary diseases and systemic infection, including agents such as Mycobacterium spp. and Leishmania spp (Shimizu, 2008). Liver disease is also reported in fattened animals (pigs and geese), in females in late pregnancy (especially cows), and in bulls, chickens and cuttlefish (Santos, 1975). In wild animals, reports of this syndrome can be found in the literature; cases of hepatic steatosis have also been described in birds (Couto, 2007), lagomorphs, rodents (Spinelli, 2014), carnivores (Armstrong \& Blanchard 2009, Martins et al., 2016) and six banded armadillo (Batista et al., 2016).

This study describes a case of hepatic steatosis in a six-banded armadillo (Euphractus sexcinctus Linnaeus, 1758) that lived illegally in captivity and was seized by the Chico Mendes Institute for Biodiversity and donated to the Federal University of Piaui.

\section{Material and Methods}

A six-banded female armadillo, of the species Euphractus sexcinctus (Linnaeus, 1758), was seized on a farm in the municipality of São Raimundo Nonato - PI, where she had been held captive. The animal was donated to the Federal University of Piaui, with the authorization of SISBIO
No. 53303 , for scientific purposes supported by the ethics committee on animal experiments (protocol 136/15).

The six-banded armadillo was sent to the Histotechnique and Embryology Laboratory at the Morphology Department for the first clinical examination, where it was found to be weak and to have numerous injuries of the limbs, head and tail (Figure 1). The animal was apathetic, with normal colored mucous. Upon radiological examination, it was found to be a young animal due to incomplete closure of the epiphysis with the diaphysis.

Thus, the specimen was euthanized following the ethical standards of the Federal Council of Veterinary Medicine. After complete disruption of vital signs, dissection of the neck was initiated to access the jugular vein; this was followed by cannulation and fixation by perfusion with $10 \%$ buffered formaldehyde followed by immersion in a tank with the same solution for 48 hours. After this period, the specimen was dissected and the observations and macroscopic findings were recorded.

The abdominal cavity was accessed by incision in the alba linea. Macroscopically, pathological liver changes were observed, including curved edges, increased size, and intense yellowish color with hyperemic and necrotic foci (Figure 2).

After macroscopic evaluation in situ and ex situ, liver, lymph node and spleen sections of about $0.5 \mathrm{~cm}$ thick were submitted to routine histological processing and stained with hematoxylin-eosin, toluidine blue and ziehl-neelsen (used 1\% aqueous hydrochloric acid) for the detection of acid-fast bacilli.

Liver histopathological analysis revealed moderate congestion of the sinusoid vessels, clear and microvacuolar degeneration of peri-sinusoidal hepatocytes, a large number of macrophages (Kupffer cells), inflammatory infiltrates diffuse with the presence of lymphocytes, plasma cells and neutrophils, and necrosis of hepatocytes. All of the above hepatic characteristics were compatible with hepatic steatosis and acute hepatitis. Acid-fast bacilli and intracellular pathogens were not detected via Toluidin Blue stain (Figure 3).

Mandibular lymph nodes showed reactive interfollicular hyperplasia, with histiocytes and mast cells surrounding the follicles. The histopathologic characteristics of the spleen indicated reactive hyperplasia of both red and white pulp (Figure 3).

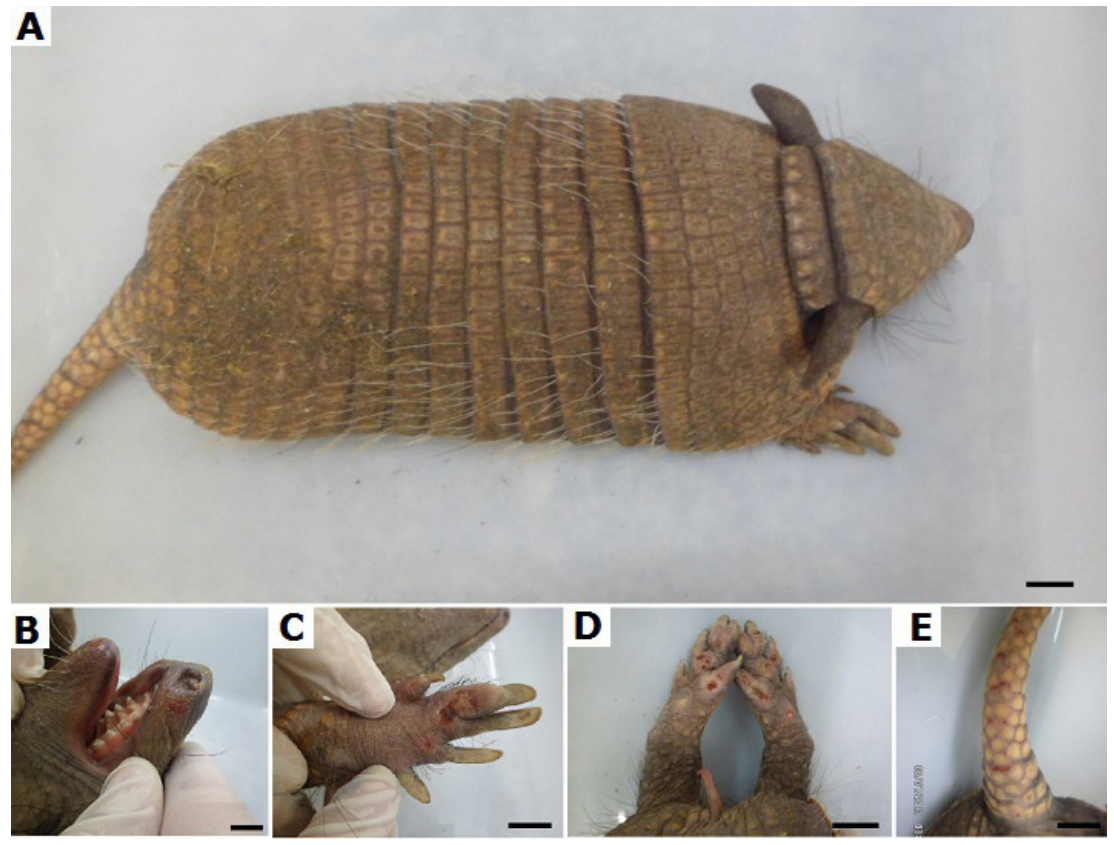

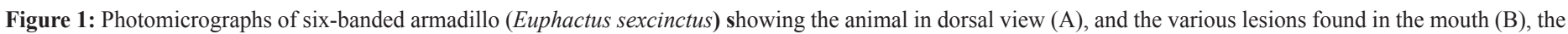
forelimbs (C), the hind limbs (D) and tail (E). Bar: $1 \mathrm{~cm}$. 

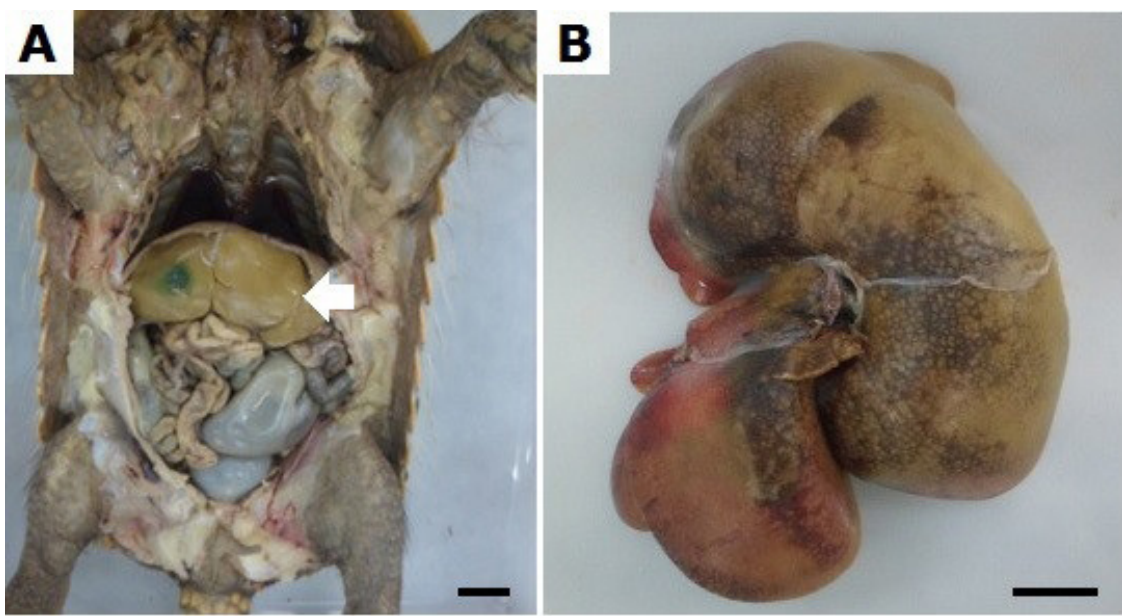

Figure 2: Photomicrograph of the six-banded armadillo (Euphractus sexcinctus) abdominal cavity after the incision and during anatomical dissection (A) showing lipemic appearance of the liver (white arrow). The right ex situ organ diaphragmatic face can be noted (B). Bar: $1 \mathrm{~cm}$
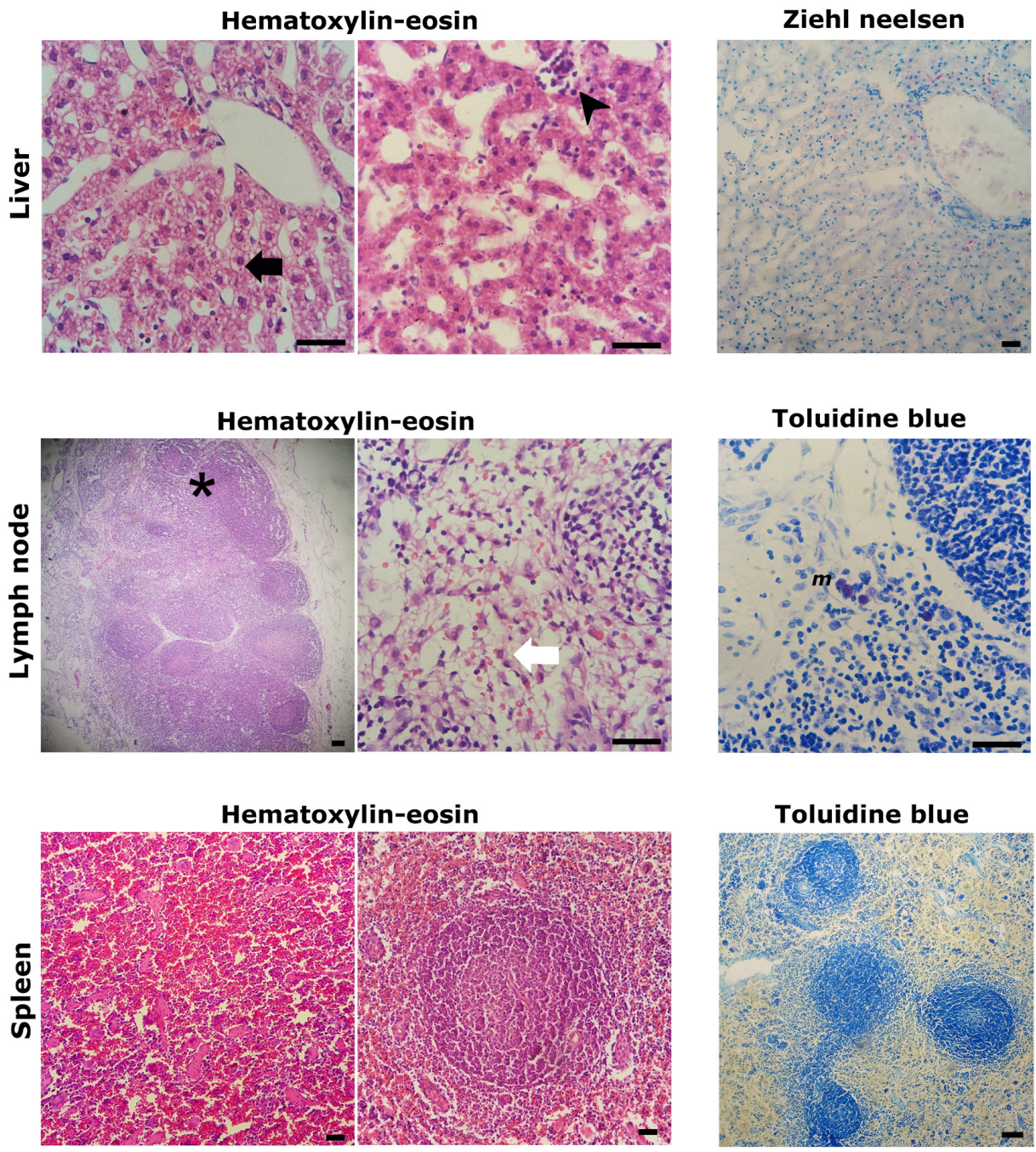

Figure 3: Photomicrograph of the liver, mandibular lymph node and spleen of the six-banded armadillo (Euphractus sexcinctus). Top left and middle images show microvacuolar

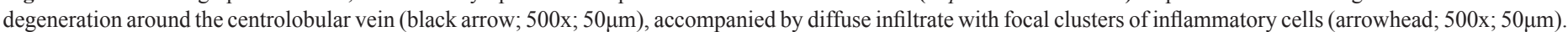

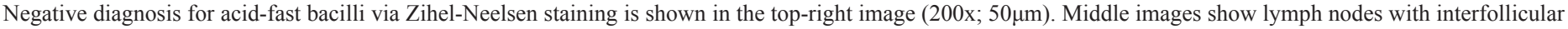

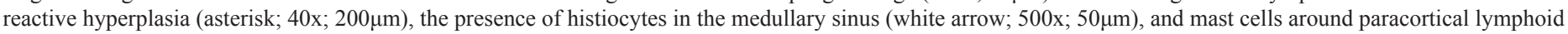
follicles $(m ; 500 x ; 50 \mu \mathrm{m}$ - Toluidine Blue). Bottom images show reactive hyperplasia of the white and red pulp in the spleen (100x, 200x - H\&E; 100x - Toluidine Blue). 


\section{Results and Discussion}

The six-banded armadillo in this report presents clinical characteristics indicative of mistreatment in captivity, which was suggested by the apathy and the injuries found, mainly on peripheral areas. The anatomical changes in the liver, indicative of fatty degeneration, may reflect a metabolic state induced by environmental factors such as stress or systemic infection.

However, a study envolved Dasypus novencinctus and Euphractus sexcinctus infected by Micobacterium leprae were full of dermal ulcers in nodular aspect (Frota et al., 2012). Lesions found in armadillo in this experiment may suggest to nerve damage subsequent to sensitivity loss caused by the etiological agent of leprosy, since they are animals that have a habit of underground digging in search of their food, but the injuries are inconclusive to diagnosis. Similar lesions can be found in the humans foots diagnosed with leprosy and experiencing metabolic diseases, such as diabetes (Boulton, 2012).

Typically, triglycerides are ingested with food and cleaved by the lipase enzyme into fatty acids and glycerol, which are stored in the liver (Jensen-urstad \& Semenkovich 2012). Since the body needs energy, the liver triglycerides are converted into free fatty acids in the circulation and oxidized to produce metabolic energy. Several factors require the production of free fatty acids, among which are the hormones cortisol, adrenaline, and noradrenaline (released in situations of stress) (Moon et al., 2002), and toxins produced by pathogenic microorganisms, for example, Mycobacterium spp, Leishmania spp and Trypanosoma spp (Coash et al., 2012).

Stress can be considered a triggering factor of mobilization of lipids to the liver, as it causes the chronic release of free fatty acids into the bloodstream and storage in the liver in the form of triacylglycerides (Rodrigues, 2009). The proposed stress-related mechanism for liver steatosis is based on the notion that the release of catecholamines (adrenalin and nor-adrenaline) promotes the activity of lipases (specifically, hormone sensitive lipase, which preferentially hydrolyses diacylglicerol generated by the activity of adipose triglyceride lipase or ATGL) (Jaworsku et al., 2007, Nieminen et al., 2009). This in turn results in mobilization of fatty acids from adipose tissue to the blood, ultimately favoring the accumulation of hepatic triglycerides (Rodrigues, 2009, Silva, 2012).

Alternatively or complementing the above described hormone-dependence mechanism, chronic stress might lead to liver steatosis via an inflammation-mediated process. This possibility is supported by observations of an enhanced expression of different pro-inflammatory cytokines by visceral adipose tissue in a rodent experimental model of stress-induced steatohepatitis (Liu et al., 2014). In addition to stress, liver steatosis can be related to endocrine, nutritional, or metabolic disorders, as well as other inflammatory diseases of the liver, pancreas and adjacent structures (Richter, 2005).

Recently, researchers reported an occurrence of hepatic lipidosis in six banded armadillo bred in captivity. However, the pathogenesis is a consequence of the caloric diet that animals receive leading to obesity and the diffuse intracytoplasmic vacuolation of hepatocytes without compromising the lymphoid system organs (Batista et al., 2016).

Among other inflammatory processes that can cause liver disease are those associated with pathogen infection. In support of this possibility, we observed reactive hyperplasia in submandibular lymph nodes and spleen. Reactive interfollicular hyperplasia with a high component of cells of the monocyte-phagocyte lineage has been associated with active presentation of pathogen-derived antigens (Keller et al., 1972, Ozawa, 2015). Whether the observed reactivity is the result of a viral, bacterial or parasitic infection remains to be determined. We were not able to detect intracellular pathogens via Zihel-Neelsen or Toluidin blue, stains useful in detecting pathogens of the genus Leishmania (Tryphonas, 1977), and Mycobacterium (Kumar, 2015). More specific tests for these and other pathogens will be required to establish a definitive diagnoses.
In wild small animals, cases of hepatic steatosis have been diagnosed in tiger cats (Martins et al., 2016), mustelids (Nieminen et al., 2009), birds, rodents (Couto, 2007, Silva \& Goncalves, 2008, Spinelli et al., 2014) and armadillos (Batista et al., 2016). The majority of these cases were associated to fasting accompanied by environmental stress, although some cases involved a high-calorie diet or inflammatory disease, as was the case of cholangiohepatitis diagnosed in tiger cat (Leopardus tigrinus Schreber, 1775) (Martins et al., 2016) and the hepatic lipidosis in armadillos bred in captivity (Batista et al., 2016). To the best of our knowledge, this is the first report of fatty liver disease in an armadillo suggests an acute infectious process with lymphoid system involvement. Armadillos are endangered animals, which have been heavily exploited for hunting, food and popular culture, and at the same time are involved in numerous cases of zoonosis (Richini-Pereira et al., 2014, Elsayed et al., 2015). Clinical case reports describing spontaneous pathological states in these animals are key for the improvement of natural and, when necessary, captivity environments, for both the conservation of these species and the development of zoonosis-related research.

\section{Acknowledgments}

We thank to Federal University of Piaui and Chico Mendes Institute of Biodiversity.

\section{Author's Contributions}

- ABSS: Substantial contribution in the concept and design of the study and contribution to data collection;

- MSR: Contribution to data analysis and interpretation;

- AVP: Contribution to manuscript preparation;

- AMCJ: Contribution to critical revision, adding intelectual content

\section{Conflicts of interest}

The author(s) declare(s) that they have no conflict of interest related to the publication of this manuscript.

\section{References}

ARMSTRONG, P.J., BLANCHARD, G. 2009. Hepatic Lipidosis in Cats. Veterinary Clinical Small Animal, Minnesota. 39(3):599-616.

BATISTA, J.S., FREITAS, C.I.A., PAIVA, K.A.R., SILVA, J.B., BEZERRA, F.S.B., OLINDA, R.G., FERNANDES, T.M., OLIVEIRA, A.F. 2016. Hepatic Lipidosis in Banded Armadillos (Euphractus sexcinctus) Bred in Captivity. Acta Sci. Vet. 44(0):1-4.

BOULTON, A.J. 2012. Diabetic foot-what can we learn from leprosy? Legacy of Dr Paul W. Brand. Diabetes metab. Res. Rev. 28(S1):3-7.

COASH, M., FOROUHAR, F., WU, C.H., WU, G.Y. 2012. Granulomatous liver diseases: a review. J. Formos. Med. Assoc. 111(1): 3-13.

COUTO, E.P. 2007. Lipidose hepática e obesidade em Psitaciformes. Thesis, Specialization Course on Wild Animals at the Veterinary Clinic, São Paulo.

ELSAYED, G., ELSAYED, M., CLINCEA, R., TALlEY, J., IGNACIO, M., THOMPSON, J.C. 2015. The curse of the Nine-Banded Armadillo: case report and review. Mil. Med. 180(7):861-866.

FROTA, C.C., LIMA, L.N.C., ROCHA, A.D.S., SUFFYS, P.N., ROLIM, B.N., RODRIGUES, L.C., KERR, L. R. S. 2012. Mycobacterium leprae in six-banded (Euphractus sexcinctus) and nine-banded armadillos (Dasypus novemcinctus) in Northeast Brazil. Mem. Inst. Oswaldo Cruz. 107:209-213.

JAWORSKU, K., SARKADI-NAGY, E., DUNCAN, R.E., AHMADIAN, M., SUL, H.S. 2007. Regulation of triglyceride metabolism.IV. Hormonal regulation of lipolysis in adipose tissue. Am. J. Physiol. Gastrointest. Liver Physiol. 293(1):1-4. 
JENSEN-URSTAD, A.P.L., SEMENKOVICH, C.F. 2012. Fatty acid synthase and liver triglyceride metabolism: housekeeper or messenger?.Biochim. Biophys. Acta. 1821(5):747-753.

KELLER, A.R., HOCHHOLZER, L, CASTLEMAN, B. 1972. Hyaline-vascular and plasma-cell types of giant lymph node hyperplasia of the mediastinum and other locations. Cancer. 29(3):670-683.

KUMAR, S.V. 2015. Ziehl-neelsen (ZN) stained method: presence and absence of acid fast bacilli (AFB) of Pulmonary and non pulmonary tuberculosis patients under went anti-tuberculosis treatment. Int. J. Pharm. Technol. 8(5):529-532.

LIU, Y.Z., CHEN, J.K., ZHANG, Y., WANG, X., QU, S., JIANG, C.L. 2014. Chronic stress induces steatohepatitis while decreases visceral fat mass in mice. BMC. Gastroenterol. 14(106):1-8.

MARTINS, M.C., MARQUES, G.C., TEIXEIRA, C.R. 2016. Case Report - hepatic lipidosis in the small jungle cat (Leopardus tigrinus). Congress of Zoos and Aquariums Society of Brazil. Society of Zoos and Aquariums in Brazil. 223 p.

MOON, Y.S., LATASA, M.J., GRIFFIN, M.J., SUL, H.S. 2002. Suppression of fatty acid synthase promoter by polyunsaturated fatty acids. J. Lipid. Res. 43(5):691-698.

NIEMINEN, P., MUSTONEN, A.M., KARJA, V., ASIKAINEN, J., ROUVINENWATT, K. 2009. Fatty acid composition and development of hepatic lipidosis during food deprivation-mustelids as a potential animal model for liver steatosis. Exp. Biol. Med. 234(3):278-286.

OZAWA, M.G. 2015. Dasatinib-related Follicular Hyperplasia: An underrecognized entity with characteristic morphology. Am. J. Surg. Pathol. 39(10): 1363-1369.

RICHINI-PEREIRA, V.B., MARSON, P.M., HAYASAKA, E.Y., VICTORIA, C., SILVA, R.C., LANGONI, H. 2014. Molecular detection of Leishmania spp. in road-killed wild mammals in the Central Western area of the state of São Paulo, Brazil. J. Venom. Anim. Toxins. Incl. Trop. Dis. 20(27):1-7.

RICHTER, K.P. 2005. Liver disease and hepatobiliary system In Gastroenterologia de pequenos animais, Tams, T.R., editor. Roca, São Paulo, São Paulo, p. 295-315.

RODRIGUES, T.M.A. 2009. Lipidose hepatica felina. Thesis, Paulista State University, Botucatu.

SANTOS, J.A. 1975. Patologia especial do aparelho digestivo. In: Santos JA (eds.). Patologia especial dos animais domésticos, volume 1. Rio de Janeiro: Biblioteca Orton IICA. p. 415-564.

SILVA, F.C.H.S. 2012. Lipidose hepática felina. Thesis. Technical University of Lisbon, Lisboa.

SILVA, L.B., GONCALVES, P. 2008. Degeneration fat (hepatic lipidosis). Rev. Cient. Eletrônica Med. Vet. 10(1):1-5.

SHIMIZU, Y. 2008. Liver in systemic disease. World J Gastroenterol. 14(26): 4111-4119.

SPINELLI, M.O., CRUZ, R.J., GODOY, C.M.S.C., MOTTA, M.C., DAMY, S.B. 2014. Seasonal variation of the biochemical parameters of rodents and lagomorphs the vivarium of the Faculty of Medicine, University of São Paulo, São Paulo, Brazil. Rev. Bras. Med. Vet. 36(2):219-225.

TRYPHONAS, L. 1977. Visceral leishmaniasis in a dog: clinical, hematological and pathological observations. Can. J. Comp. Med. 41(1):1-12.

Received: 11/09/2017

Revised: 06/01/2018

Accepted: 12/01/2018

Published online: 01/02/2018 